\title{
The reformation of space for public worship: Past and present - Continuing the discussion
}

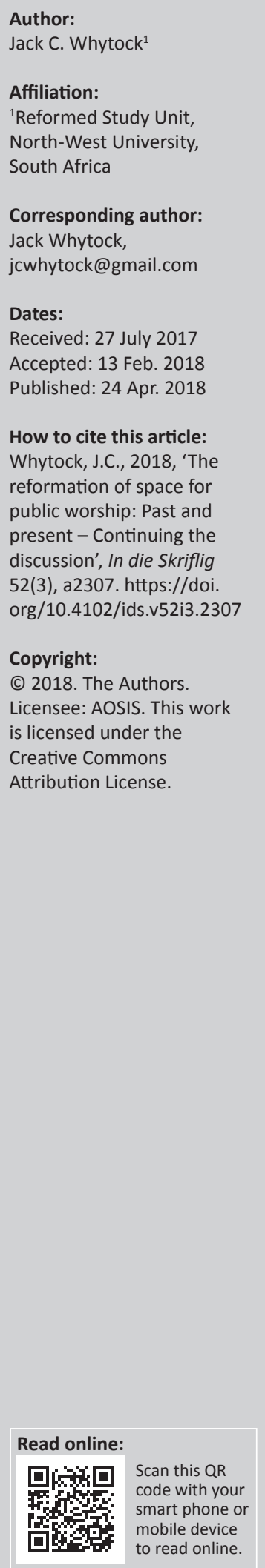

\begin{abstract}
In the light of the 500th anniversary of the Reformation, this article will explore a neglected area of Reformation studies namely the reformation of space for public worship in the past and the present. The article has three parts: first, a general survey of worship space at the eve of the Reformation; second, the response of the Magisterial Reformers (with a focus upon those who would be classified as reformed) to the space for public worship by principle and actuality; and third, the ongoing use of space for public worship chiefly in the evangelical and reformed tradition. On this final point specific examples will be included concerning public worship space in the contemporary context. The article is an introduction in what is really a broad interdisciplinary approach raising matters related to church history, theology, liturgics, aesthetics, stewardship and architectural design in a general manner and will make suggestions for further ongoing discussion. This article endeavours to help by providing an historical context for further discussion of the subject matter of the use of space in public worship and it is hoped that further articles will follow from this introduction to the subject.
\end{abstract}

Although we have recently been focusing upon the 500th anniversary of the Reformation, one senses predictability in the themes explored: salvation, authority, polity and church governance, worship, the Christian life, ecclesiology, sacraments, education, the Kingdom and the key leaders which are all very good themes. However, a particular area which is rarely addressed is the impact of the Reformation upon the 'space' set-aside for public worship. Often this particular theme is muted in the reformational church history courses or lectures.

Before proceeding to the body of this article, a brief comment needs to be made about space. The word space has taken on a significance of its own in recent years. 'Space' was formerly known by other words such as place, location and building. The word space itself is a neutral word and often depends upon the adjectives used with the word such as 'sacred' space to give it a certain added meaning (Kilde 2008:3-11). Using this adjective or the one closely related - hallowed - is actually much more in the Roman Catholic, Eastern Orthodox or Anglo-Catholic traditions. This article will employ the term space without the adjective unless if taken from quotations and will use the word virtually as synonymous with 'place'. James F. White (1990) says it quite well:

Any Christian community needs a place for worship of the Incarnate One. It can be anywhere but it has to
be somewhere that is designated so that the body of Christ knows where to assemble. (p. 89, [author's
italics])

The conviction of most of the reformed branch of Reformers was that the building used for new covenant worship is not any more sacred than another place for public worship (Gobel 2011:6-7; Spicer 2002:192; 2011:86-87, 95, 97-98, 103) as for example the meeting location for worship under an acacia tree, by the river bank, a residential house or a rental lecture hall (Ac 16:13 - river bank; 18:4, 7 - purpose built synagogue building, [secular] lecture hall; Rm 16:5 - residential house). Rather, it would be best to speak of designated space rather than calling it sacred space. The debate here is extensive and is pointedly limited in this article (Gibbons 2006:1-4). 'Holy' things may take place in the designated space, but this does not mean that now the space is 'sacred'.

The purpose of this article is, firstly, to provide a popular and a brief discussion regarding the situation which the Reformers inherited at the time of the Reformation in the early 16th century concerning designated space for public worship; and secondly, how the Reformers reacted to this: Because the way the Reformers reacted to the issue of space for public worship is less than uniform, many generalities will be made in this introductory study. This article will tend towards the Magisterial Reformers of the reformed branch, but, even so, generalities will need to be made, as not everything is uniform here either. The discussion will then be carried further to a third purpose, namely to raise the question of the ongoing use of designated space for worship today 
in evangelical and reformed churches. It should be obvious that the use of designated space visibly expresses theological convictions and these will be briefly noted as the article unfolds in its three parts.

\section{Public space for worship at the eve of the Reformation}

What did the public space for worship look like at the time of the eve of the Reformation? General comments here are in order with an understanding that, without a doubt, somewhere in Europe in 1517 exceptions or unique permutations could be found. Generally the space for public worship was overall rectangular as to the footprint of the space or place with or without cross arms (transepts) and apse. ${ }^{1}$ Within this overall rectangular shape the interior focal point would be the short wall at the front. The focus of this short wall would be the high altar for the celebration of the Mass and usually screened. Often the building was configured so that this short wall was facing eastward, although this was not a universal custom by any means. In small village churches the rectangular design would be most simple and may not always have included an elaborate screened area where the high altar was enclosed behind. Also, neither side transepts nor an apse were usually present. If the building was a larger church complex, the design would include a screened chancel with rood and with two side rows for choir stalls and clergy or monks and nuns - virtually a 'church within a church'. ${ }^{2}$ The orientation of the choir stalls or rows would be more or less against the two long walls, loosely speaking, and at right angles to the altar, the apse area (Bruggink 1992:10-11; Whytock 2014:54-56; Yates 2008:7). This pattern can still be seen in ecclesiastical architecture to this day in many an Anglican church and other Protestant churches. It also has been adopted within many parliamentary traditions stemming from England, whereby the House of Commons has a dais where the high altar would have been and two rows of benches on the long walls for the members of the parliament to sit (Macnutt 2010:8).

Usually the main space, the nave, did not have pews, benches or permanent chairs provided for the lay people of the congregation. Pews were found in some church buildings in Europe before the Reformation, but not universally. Some churches did have some stone benches around the inside of the exterior walls as seating chiefly for the elderly (Howkins 1980:27). There is some dispute as to whether or not the space for the public to assemble (the nave) was divided by gender, but the evidence appears to suggest that generally men and women were separate from one another in the worship space and sat or stood apart from each other prior to the Reformation (Lambert 1998:122-123). There was much diversity in the public portion of the building. It appears that some brought their own stools, some kneeled, some sat on benches and others stood. This also tells us a great deal of what actually

1.'Footprint' refers to the shape of the building as outlined on the ground, similar to human footprint - the outline of the shape of one's foot pressed into the ground.

2.Another name for this is the 'two-room church' (of the Medieval Period) for the sanctuary (chancel or choir) and the nave, or the space for the clergy and the space for the people (Davies 1986:28) was going on in worship - the focus was generally not long sermons, but the drama of the altar and private worship matters (cf. Maag 2016:43; White 1990:102). ${ }^{3}$

There appears to be evidence of some departures from this general description above. For example, some evidence seems to indicate special spatial orientation may have been dualistic in that a high altar may have been on the short-front wall, but an elaborate high pulpit in the centre of the one long wall (often by a column row). This type of special orientation may have been more so with certain chapels where 'preaching' was also more particularly emphasised as opposed to the medieval norm where it was not. There is evidence that also some large church buildings had such large high pulpits in the nave portion again towards the long wall and not as a central pulpit on the short wall as that was reserved for the altar (Howkins 1980:51). These cathedral churches often had special preachers. So the changes, which many of the Reformers brought about in public worship space, were not totally without some measure of precedent. The conclusion is clear that the vast majority of prereformation church buildings were true to the spatial orientation of the general description above: the high altar on the short wall as the focal point (generally screened), a rood and a rood gallery, side-rows of stalls in a separate chancel and a more open nave for the 'people' (Bruggink 1992:10).

Another significant feature in larger churches, cathedrals, basilicas and abbey churches were side chapels. These chapels often honoured a particular saint, were oriented around a central altar and did not generally have a pulpit. The other overall chief interior feature would have been colour, imagery and containers of various shapes and sizes as well as elevated chairs for the hierarchy of the clergy or governing classes. The imagery range was vast: biblical scenes, biblical characters, church fathers, noted leaders - both ecclesiastical and civil noted saints, heroic activities remembered whether it was the slaying of a dragon or marching in a Crusade. Such imagery could be through painted frescoes, stained glass, statuary, containers or relic vessels or reliquaries and architectural structural embellishments (Taylor 2003:92-93).

The architectural styles of the pre-reformation churches display much variety. The buildings might exhibit an overall Norman, Romanesque, Gothic or Classical style (and often incorporating ancient Roman basilica floor designs). In many regards this style factor is not the most critical factor in coming to understand pre-reformation interior church space. ${ }^{4}$

3.White states that 'until the 14th century the nave was clear of chairs and pews'. There appears to be variance about just when chairs, pews or benches may have been introduced as furnishings.

4.The point can be made that all of the above-mentioned styles still used a common theological framework and had a very similar spacial interior usage and design. After the Reformation, all of these overall styles could still be found in reformation churches; yet, we will often see churches with very new spatial interior usage and design. It could, however, still be called a Gothic structure. We need to be carefu design. It could, however, still be called a Gothic structure. We need to be careful that we do not see, according to Pugin's thesis, that Gothic was the only style suited for church buildings to be reimposed upon earlier periods. Such a thesis has neve received universal inter-generational support. The reality is that, at the time of the Reformation, there was a diversity of church building styles. St. Peter's in Rome, a the centre of the Reformation, conflict was being built in the Classical style in keeping with the Renaissance. Also, many church buildings built over many years contained more than one style. Further discussion of another viewpoint can be found in Whittle (1968:40-41). 
The more significant matter is the spatial interior orientation and focus as well as the specific features of the interior and its furnishings. This is really much more significant to understand the relationship between the space designated for public worship at the time of the Reformation and what theological underpinnings are at work here.

Finally, a brief note about choir space in the pre-reformation churches: choir space was either near the high altar in the chancel area or in a rear gallery or in the rood gallery (Howkins 1980:58-61). Music accompaniment may, in some instances, have been with an organ - often again in a rear gallery or in a rood gallery although it could be situated in a variety of locations depending upon the size of the instrument (Bruggink 1992:10-11). Because it was the choristers who were the singers, those in the nave did not often participate to the same extent vocally. Some might participate, but many did not - they listened. Looking at this through the lens of the Reformers, this use of space and the lack of congregational involvement in singing represented a failure to understand the doctrine of the priesthood of all believers.

\section{Summary}

It can be said that, generally, the interiors of church buildings in Europe at the time leading up to the Reformation focused upon the high altar situated at the short wall. This was the focus - for the drama of the Eucharistic Mass. The lines were very clear - the chancel for the priests and the nave for the people. The clergy kept their back to the nave while conducting the ritual of the Mass. Generally, long preaching times were not the focus; thus, seating was not consistently patterned in the interiors. It would appear though that gender segregation was quite common as was social segregation.

The church buildings were generally open at least daily if not permanently. They were places to go and worship privately, whether to pray, to mediate, to confess - whether in the main nave or in side chapels. Thus, the interior of the buildings was much more than limited to public Sunday worship venues.

There is a clearly defined theology which emerges from looking at these church interiors: the visual drama of the Mass was the focus and a priestly ministry. There was clearly a de-emphasis almost universally upon preaching and the auditory. Related to this was often the lack of organised seats - it just was not always necessary. Singing had come to have designated space and thus limitations developed with this. Because the auditory was not the primary focus, the visual took a larger role through the development of iconography. The overall result was to see the church building as sacred space and even within it there was a more sacred space - the chancel versus the nave.

Aesthetically a sense of beauty emerged which was complex and elaborate ornamentation combined often with impressive soaring bulk at least in the larger structures. However, definitions of what constituted beauty in church buildings were not always uniform. There were attempts to move sometimes to a much plainer or minimalist approach, but this was generally a minority approach.

\section{The reformation of space for public assemblies}

There was an incredible variety in adapting medieval parish churches, cathedrals, monastic chapels and abbeys into new Protestant places for worship. It must be noted that the building of new purpose built Protestant worship places took time and did not happen immediately after 1517. Many believe that the first purpose built Protestant church was not built until 1544 in Torgau at Hartenfels Castle (Chapell 2009:15-16; Whytock 2014:63). Some of this response was more pronounced whereby new walls were constructed in some medieval cathedrals or abbey churches. This could be where the screen was: now a wall appeared so that the congregation could be in the nave and a new school in the former chancel or vice versa. In some cases, even a portion of the building was completely abandoned (Spicer 2011:84-85; White 1990:103).

For many, following the reformed branch of the Reformation, the focal point of the interior moved now from the high altar to the high pulpit located either on the short-wall or on a side long wall. An example of this was at St. Peter's Geneva, where, in Calvin's church, the pulpit was moved in 1541 to a side long wall by an aisle column support before the north transept. The screen, altar and chancel stalls were all removed (Davies 1986:34). Galleries were then added in the two transepts and the chancel to facilitate the closeness of the people gathered around the word (Brightman 1976:78). The result was the congregation were now around the pulpit in the shape of a star design, at the front of the nave and in the two transepts and in the former chancel. ${ }^{5}$ The pulpit spoke of the importance of the Scriptures and of providing a desk for the preacher to have freedom for preaching (White 1990:96). These high pulpits were massive and could display remarkable craftsmanship. The Protestants were not the first to construct such massive pulpits. There was precedence before and during the Reformation whether in a cathedral or by Jesuits who also were constructing such pulpits in some places in the 16th century (White 1990:102).

The raised pulpit allowed the preacher to have better eyecontact and also was viewed as a way to aid audibility. To help further with the audibility, a sounding board was often constructed above the pulpit. The point is clear - the Word is to be read and preached with effect to be heard by all in the interior or meeting space. Going together with the pulpit is seating. A move to universal seating in Protestant churches

5.It should be noted that this is not exactly the way it is today at St. Peter's, Geneva Care always needs to be taken when discussing church architecture that we do not Care always needs to be taken when discussing church architecture that we do no come to the following conclusion, namely as we see things today, that is how they were originally' - either by the Reformers and what they did to reconfigure space or what later generations did in reconfiguring an evangelical and reformed church interior in the early 20th century for example (Whytock 2014:56). Also, one does wonder if this star-shape in 1541 was Calvin's ideal that a church be built more in the round as did occur in some of the French reformed temples (see Maag 2016:45) and the Temple de Paradis. 
became the norm. Before it was haphazard, but now it was to become universal. Thus, moveable benches or fixed pews started to appear with much more regularity; although, stools were still also encouraged in many congregations where benches or pews had not been completely provided (Spicer 2003:411-414, 421). The sermons were now longer and hence the practical need for seating was necessitated. The emphasis was upon learning together as a community the truth of God's Word. Benches and stools are still allowed for flexibility and movement of the space to accommodate communion tables. Pews usually are fixed and do not allow as much flexibility; thus, aisles or space near the pulpit must be provided for communion tables.

In terms of seating gender, segregation appears to have been fairly universally practiced in the early reformed churches whether in Switzerland or Scotland. Partly it may have been custom from the pre-reformation period and partly to imitate the Early Church, but it was also thought as a way to be less distracting to separate men from women (Spicer 2003:415, 421).

The next major change was the space to be provided for the communion table or tables especially for many within the reformed branch. These tables were to be constructed of plain wood and had to look like a table and not, in any way, like an altar. Hence, no box tables were made. ${ }^{6}$ This was a matter of deep theological conviction and not a legalistic issue. The rationale here was most significant - there was nothing of the sacrifice of the Mass with a table and it was making a statement of the familial aspect of the sacrament.

Space was to be made whereby the people could come in relays to the table(s) and either stand or be seated - again by gender. These tables were mobile. Hence, some were made according to a collapsible trestle style (often plain boards placed on trestles for the ease of assembling and dismantling) and often were not seen or kept in the interior if communion was not being observed on that specific Sunday (Brightman 1976:78; Demura 2008:177-178, 183; Whytock 2014:53-64).

There is no evidence in the reformed branch of the Reformation that eating meals or serving beverages after or before the services of public worship ever took place in the church interior space. This was in many ways something which would develop later with more pietistic groups through the agape love feast or with Anabaptists, but not with the Magisterial Reformers. ${ }^{7}$ This raises the question whether this was viewed as a very important aspect of the use of church interior space? The answer is simply no. Provision for eating and drinking was not in the church interior and therefore there was no need for kitchens either. Thus, nonmoveable seating (fixed pews) was slowly to become the

6.Modern box tables in some evangelical and reformed churches often did not emerge until the liturgical changes of the later 19th century.

7.The evidence is not conclusive that the Reformers were reacting against some medieval churches where, in the nave, dances, eating, drinking and plays were conducted (Davies 1986:388) norm as the only space needed for some movement around the communion tables.

Baptismal fonts remained in the buildings, but sometimes they changed locations - migrating from the entrance door closer to the pulpit area. This, too, was making the point that the sacrament was not a private family matter, but a matter for the whole congregation to witness. Special fonts for holy water were destroyed or abandoned. Also baptismal fonts generally became less elaborate and many were 'basins or bowls' placed near the pulpit or attached to the side of the pulpit with a bracket (Bruggink 1992:10; Davies 1986:369).

What did the Reformers do with the chancel or choir stalls? Again the answer varies. Some removed them altogether as in the case of St. Peter's (St. Pierre), Geneva. Others kept them, but basically the chancel became an unused space. Others walled it off (Yates 2009:30); others retained it for a 'choir' or for the leading singers. The change was more in the direction of full congregational singing. However, the school boys often sat in front of the pulpit and they became the leaders of congregational praise (as at St. Peter's, Geneva). Some Scottish churches also had designated space for pupils who helped with the singing (Spicer 2003:416). Therefore, in some respects the 'chancel choir' moved into the nave whereby all sat together to praise the Lord as one congregation.

The story is well known concerning colour, imagery and containers. Iconoclasm occurred and again various forms of the reformation of interiors of imagery occurred. The relics of the saints were removed, the walls were often coloured white and many stained glass windows were destroyed or removed. Some churches had texts of Scripture painted upon the walls or upon boards in the main meeting area. The move, especially by the reformed branch, was towards simplicity and plainness. It has often been said that there was no longer an aesthetic of beauty. This is actually misleading as any interior designer today will confirm that minimalism has its own aesthetic of beauty. Think of the contemporary world of design and one can quickly see this. Beauty should not be limited here to the visual, as it may be argued that there was also a beauty in the new manner of singing and the artistry of this would also need to be properly considered.

Immediately after the Reformation, in many reformed areas, the church buildings were locked outside of public worship times. This was a change from the pre-reformation period. It was to break with the past about the space being used for private worship practices - many of which were viewed as non-biblical (Spicer 2011:88). The point was perhaps needed due to immaturity of development, but often one reaction can lead to another problem. Could it be that from this a conviction developed inadvertently that the building was sacred or holy and only for worship, and not to be used for any other purpose such as eating or drinking a beverage in the worship space? The question is worthy of consideration. ${ }^{8}$

8.1 myself have had reformed people tell me that serving coffee in the place where worship was conducted, is not appropriate. This does appear to support a view of 'sacred space'. 
Finally, the Reformers were not necessarily all of one opinion or conviction, but clearly there was a move towards seeing the space where the congregation gathers as a 'place' and not as 'sacred' space. It is their space to meet, but it is not sacred. The Reformation would work through stages in its developmental history. The Puritans began to use the term the meeting house for the place they meet. This clearly is to make the point: the church is the people of God, not a building. Hence, it really does not fit to describe a reformed building as a sacred space for many within the reformation context (Gobel 2011). ${ }^{9}$ The Anglican branch may have various streams of thought within it on this as may the Presbyterians currently or even historically. ${ }^{10}$ In France the worship space after the Reformation was extremely varied: barns, houses, outdoors and sometimes new purpose built places, generally in a Classical style such as temples.

\section{Summary}

The Magisterial Reformers (reformed), based upon theological and liturgical principles, transformed the interior space of the existing medieval churches by making the focal point the pulpit (Bruggink \& Droppers 1965:8081). The exact location of this appears to be usually to one side of the long-wall, but, again, not universally. Generally the screens were removed at the chancel. With the emphasis upon the auditory, fixed seating arose and became much more common after the Reformation. The seating plan could vary as to shape and was also generally gender segregated. Singing was more emphasised through full congregational singing, but could be led by one group; yet, all were to participate. Thereby, the chancel choir stalls were not universally used. Thus, people and clergy were brought much closer together -not in 'two rooms' (Whittle 1968:39). The interiors also underwent a movement to a much plainer appearance, but yet with a beauty still present. Portable communion tables were introduced for communion times and were made of wood. The interior space was used only for preaching and teaching meetings, but not for what our modern age would call 'fellowship' times. Tensions arose, however, over civil seating in these newly designed interior spaces (Spicer 2003:405-422). For some of these matters summarised here there are some medieval precedents; yet, these are muted and not general.

\section{Reformed and reforming: The use of space for public worship today ${ }^{11}$}

Is there still a latent pre-reformation attitude or theology sometimes expressed by evangelical and reformed Christians with statements such as 'they worship in an industrial warehouse or a hotel dance-room - I want to worship in a

9.This Christian magazine was one of the few popular Christian magazines which have found to actually devote a cover to the theme of church architecture.

10.For a helpful article upon the tensions within Scottish Presbyterianism and Scottish Episcopalianism on space or sacred space of the early 17th century, see Spicer (2011:81-103).

11.I think it is appropriate to apply the dictum Semper Reformanda to this discussion on church architecture. proper church'? ${ }^{12}$ How does this reflect the words of Jesus to the Samaritan woman:

... a time is coming when you will worship the Father neither on this mountain nor in Jerusalem ... true worshippers will worship the Father in spirit and truth, for they are the kind of worshippers the Father seeks. (Jn 4:21, 23 - NIV 1984)

Is it possible to make Protestant church buildings our holy or sacred places so that we lose the spirit of flexibility which is actually biblical and theological? We will explore these questions now through some specific examples.

Let us begin with fixed seating of pews or moveable benches or chairs. Fixed seating greatly limits what can be done in a space. The use of chairs, which can be quickly stacked or moved, immediately changes or transforms a space as to its function. It means that the space can quickly be converted into a space where food and drinks can be served and conversation can take place. The space can also become a place for a game of floor-hockey or aerobic classes, or a sleepover by a youth convention. Are any of these activities incompatible with Christians doing such when they gather or should they do these activities in space never used for public Sunday worship? Do economics allow for a space reserved only for Sunday public worship to be built to accommodate for example 300 people plus another public space built for eating or playing a game for 200 people? Economically and also aesthetically it may be very advantageous to have two separate spaces, but is it necessary from a biblical and theological vantage point of new covenant community? The biblical rationale is very difficult to find, but perhaps economically some congregations can afford two such spaces and this may be much more aesthetically pleasing. John Calvin, in Book III of the Institutes, warns his readers of ascribing to our church buildings 'hidden holiness' (Maag 2016:110). Even though we may confess that in evangelical and reformed churches we do not subscribe to the statement of sacred space, there does appear at times to be a hearkening back to such thinking. The reformation of space has not completely ended. ${ }^{13}$

Holistic ministry recognises the value of believers eating together and visiting with one another. Pews are a relatively modern circumstance and they do place limitations upon space for such eating of informal gatherings. I remind readers of many encounters which I have experienced in Africa, Asia and South America where, immediately after the communion service, the white plastic chairs are moved around to allow for easier service of the hot food and sodas in the same space.

12.As a church planter many years ago I received this comment many times from folks who adamantly told me that they were 'Reformed'. I would reply, 'Yes, we worship in space which was often a bar and a dance hall Monday through Saturday.'

13.On the website of Saint Andrew's Chapel, Florida, the church where the late R.C. Sproul ministered, the following was stated about worship in this modern Gothic revival building:

The sanctuary is a holy place for the worship of a holy God. The architectural design of the sanctuary is in accordance with the traditional cruciform pattern. Worshipers enter through the darkness of the narthex and into the light of Worshipers enter through the darkness of the narthex and into the light of the sanctuary radiating from the stained glass windows adorning the chancel and sanctuary. This is a reminder that when we come to worship in the sanctuary, we cross the threshold of the secular to the sacred, from the common to the uncommon, from the profane to the holy, from darkness to light. (Saint Andrew's Chapel, Florida 2017) 
Yes, meals are served in the same space where a few minutes ago public worship was conducted as men and women sat segregated by gender. It all seems rather in keeping with the church being a people and with practical financial realities for many Christian communities where the luxury of two spaces is not feasible (Wilson 2001:87-88). ${ }^{14}$ There appears to be no evidence that evangelical and reformed churches ate together 400-500 years ago in a worship space. Yet, they were very flexible in transforming their space which they inherited into new preaching and teaching places. I would assert the continuing transformation of ministry does not need to end with how the Reformers transformed their inherited space.

Allow me to reflect over a worship experience which I recently had in London, England. It was at London City Presbyterian Church on Sunday 19 November 2016. They gather in the historic 1788 building of St. Botolph-without-Aldersgate with the adjacent courtyard where John Wesley was converted. The building they worship in is an elegantly adorned classical Georgian church. The interior is a three-sided gallery with central aisle and apse, choir stalls with no rood screen as well as a side high pulpit and communion table against the apse wall. The interior has been modified with chairs in threequarters of the main floor seating area and fixed pews remaining at the back and in the gallery. The large baptismal font remains in the building near the front left door. The interior pattern is quite typical of many church buildings in London built after the style of Wren and St. Martin-in-the Fields or All Souls Langham Place by John Nash. St. Botolphwithout-Aldersgate bears the marks of a modified postreformation plan for many Anglican churches or even for many Presbyterian churches. The London City congregation worships in this space. The Sunday I worshipped there they used a central small lectern and then after the service there was a meal served in this same space. The chairs were all moved and tables were brought out for people to sit around. Tables were laid out down the centre aisle and across the front. Food was served under a gallery aisle. Then we listened to a mission presentation with informal questions at the conclusion of the meal. Folks stayed for some time visiting and talking in this space. There is no immediate church hall or fellowship hall nearby. So, if food is served it seems there is only one space available to do such other than eating outside in the courtyard which was not feasible given the late November weather in London. One notes that the building has undergone modifications, especially as regards fixed seating. The result is really a space with both fixed and moveable seating - something which is actually becoming quite common now in many United Kingdom church buildings. The alternative is to try and dig a space underneath the building for a hall or else go off-site to locate another space for a hall. Economic realities would appear to be again at the forefront and also a change in thinking whereby a holistic ministry is being developed. The high-pulpit was not used as currently often the case in many of these older churches. Instead, a small portable lectern is placed in the centre of the

14. Wilson's suggestion appears to be more in the direction of having two separate spaces if I am interpreting this correctly. I suspect the date 2001 may be part of the context for reading this suggestion and today this may not be written in the exact same way [author's supposition] short-wall (front). The sermons were about 35 minutes at each service that day. To sit was thus preferable rather than having to stand for the sermon. It thus appears that the tradition has been established: post-reformation people, gathering to hear the Word of God expounded and be seated to aid one's concentration, was in evidence. The question remains: Are two spaces needed or can one space be multi-purpose both for public worship and for congregational fellowship, eating, informal talks and open discussion, or is there a fundamental violation of biblical principle in this 'movement' and arrangement? I answer in the affirmative that what we are really seeing is consistent with the reformed principle of the use of space not as sacred, but as the place to meet. In many ways this is an illustration of ongoing reform and flexibility. ${ }^{15}$ To become slaves to all aspects of space as adopted or implemented by evangelical and reformed churches at the time of the Reformation can be very problematic. We actually become slaves to a new tradition of space.

Let us take another example: The month before, I worshipped at St. John's United Church (local union congregation of evangelical Protestants: Presbyterians, Anglicans, and Methodists) in Fort Beaufort, Eastern Cape, South Africa on Sunday 23 October 2016. This is a modest Gothic revival church building with a large pulpit on the right, a lectern on the left and a choir area behind. It was a Presbyterian church building. We worshipped in the church space and then after the service a fellowship meal was served in the adjacent space of the church hall - a former building for worship until the new Gothic church was built. This Gothic church has fixed pews which are, as the word fixed implies, not moveable. Thus, it is rather difficult to drink and eat in this space and therefore the use of the adjacent hall next door. This meal allowed students who were with me to visit members of the congregation, and vice versa, to become acquainted with each other. I believe this is a very vital aspect of Christian and theological college life. A PowerPoint slide presentation about the theological college and the students could be observed while the offering was being received in the worship space building. Such technology was not used during the Reformation. The announcements often are presented on the PowerPoint before the service begins for the congregation to note these and they are then reinforced in the weekly bulletin. I have found many congregations running announcements on PowerPoint projection prior to a service. In evaluating these spaces, there was at some point sufficient funds to actually create two separate spaces. Printed hymnbooks and Bibles were used in the service as well as PowerPoint for the missions spot and also for announcements. It was a modest use of technology. Others will make use of PowerPoint much more. In contrast with the two churches above, economics actually appears in many ways to dictate how holistically space is used.

15.I recently (26 November 2017 ) toured the building site for the new Stranmillis Evangelical Presbyterian Church in central Belfast, Northern Ireland. This church is constructed on a very expensive and small building plot across from Queen's constructed on a very expensive and small building plot across from Queen's
University and the former one hall church building was demolished to make way University and the former one hall church building was demolished to make way
for this new building. The new design is to build up with a main hall on the ground for this new building. The new design is to build up with a main hall on the ground floor which will be designed to be flexible for worship and as a multi-functional
area. Clearly this is a meeting place, but not a sanctuary of sacred space (Stranmillis Evangelical Presbyterian Church 2015:4) 
The issue of modern technology has been raised. Regarding technology some discussion begins to emerge as to how technology is affecting the space of public worship, but this appears to be at a very elementary stage. In designing new worship space the trend is to use more elaborate sound systems and visual boxed areas or designated areas for technicians. There is also a trend to redesigned platforms to accommodate the praise team or band. Generally, moveable seating replaces fixed seating and there is also easy access to coffee and refreshments nearby with a large foyer area or welcoming area. Not all of these redesigns features are negative. However, these redesigns raise some theological worship questions: Do they represent visibly a shift towards more entertainment focused worship rather that congregational participatory worship, especially in singing? A recent trend has been discussed lately, namely the decline in Protestant congregational singing. Is it a move towards a pre-reformation mode of singing? There are a multitude of factors at play here, but one shift that is being observed is in the actual design and layout of the worship space. Formerly, there may have been space for one organ, but now there is a large platform like a darkened theatre stage area designated for the musicians with questionable results (Lamm 2017:para.5).

\section{Summary and conclusion: Areas for discussion}

Circumstances have changed from the days of the Reformation. Yet, the audible preaching of the Word was still carried forth in both of these very different locations in London, England and in Fort Beaufort, South Africa as described above. A discussion could take place on this aspect of Word centeredness and also adiaphora for multifunctionality as in the one space. Overall, the focus of these contemporary examples is about Word centred worship, holistic ministry, the concept of multipurpose space and flexibility. These are the key facets for ongoing discussion. There are many more contemporary applications which also need to be included in these discussions, namely new technology, the question of entertainment versus congregational participation vocally and financial stewardship (Starke 2011).

The Magisterial Reformers had guiding principles when they began to redesign their places of worship and these principles were all tied with theological underpinnings (Bruggink 1992:10). Much can be said about this subject of guiding principles and a whole range of contemporary works can be included here to engage in more extensive discussion on the nuances of that subject (Gore 2002:54-70; Old 1984:8). The changes, which the Reformers enacted from the Medieval period, have been duly noted in this article. Yet, to become slaves to all the ways, the fact that Magisterial Reformers redesigned and designed their places of worship, is not right either and misses a spirit of Christian flexibility - adiaphora. On this 500th anniversary of the Reformation we need to reassess the guiding principles which the Reformers saw as essential in their places of worship and then work these out in our context. There is incredible flexibility that must be guided by principles rooted in the Scriptures about public worship space. There is still much work to be done here.

Other areas needing to be addressed include theological institutions training students, for the ministry need to see that their curricula also includes fuller discussions on the use of space - both before and during the Reformation, and today. Teaching exclusively about the Reformation iconoclastic wars is not providing a full enough historical and theological picture. Likewise, ministry courses in liturgics and pastoral ministry as well as theological courses in ecclesiology and the sacraments are excellent opportunities for students to analyse more fully the design and use of space for public worship as an expression - whether consciously or not of theological and biblical principles and for holistic ministry. The use of technology must be included in these curricula courses.

Another possibility is that Christian liberal arts universities may elect to conduct elective courses about church architecture in general and then reformed church architecture specifically. Brightman (1976:75-82) wrote about an innovative way of teaching theology and liturgics through an alternative course in church architecture. Others have recognised that studies such as the phenomenological study of the places of worship can be worthy exercises for teaching (Marvell 1984:1-32).

Also reformed graduate or post-graduate theological institutions should be encouraging thesis level research on this interdisciplinary theme: liturgy, theology and church architecture (space) - historically and for today. We have not been very creative in this area of research (Working 2013:5363) and more could be done here (Chernoff 2012:1-17; Kirschner 2009:5-6; Seasoltz 2005:1).

Both theological institutions and the worship and doctrine committees of denominations must engage in this discussion. There are issues here with large implications and perhaps with concerted discussion, guidelines may emerge to help churches as they plan, redesign and implement spatial developments and liturgical proposals. A fresh re-exploration of our own heritage is needed so that we will be better equipped to enter more fully into the current discussions which are actually well underway, but often without theological reflection. Denominational printed and electronic magazines as well as church conferences should be also used as forums for discussions and education on this subject.

\section{Acknowledgements}

The author would like to thank several ministers in South Africa and in the United Kingdom; members of the Society for the Study of Architecture in Canada; and also the late Canon Robert Tuck in particular. The author thanks those who have discussed this subject, related earlier articles, and have graciously unlocked church buildings for the author. 


\section{Competing interests}

The author declares that he has no financial or personal relationships which may have inappropriately influenced him in writing this article.

\section{References}

Brightman, R.S., 1976, 'Church architecture as an approach to the study of religion', Horizons: The Journal of the College Theology Society 3(1), 75-82.

Bruggink, D.J., 1992, 'Architecture, church', in D.K. McKim (ed.), Encyclopedia of the Reformed faith, pp. 10-11, Westminster/John Knox \& Saint Andrew Press, Louisville, KY.

Bruggink, D.J. \& Droppers, C.H., 1965, Christ and architecture: Building Presbyterian/ Reformed churches, Eerdmans, Grand Rapids, MI.

Chapell, B., 2009, Christ-centered worship: Letting the Gospel shape our practice, Baker, Grand Rapids, MI.

Chernoff, G.T., 2012, 'Building the Reformed Kirk: The cultural use of ecclesiastical buildings in Scotland, 1560-1645', PhD thesis, University of Edinburgh.

Davies, H., 1996, Worship and theology in England: From Cranmer to Baxter and Fox, 1534-1690, Book I, Eerdmans, Grand Rapids, MI.

Davies, J.G., 1986, 'Architectural setting, "Nave"', in J.G. Davies (ed.), The New Westminster dictionary of liturgy and worship, pp. 28-34, 388, Westminster Press, Philadelphia, PA.

Demura, A., 2008, 'Calvin and à Lasco: A comparative study of two ecclesiastical ordinances', in H.J. Selderhuis (ed.), Calvinus sacrarum literarum interpres: Papers of the International Congress on Calvin Research, pp. 172-189, Vandenhoek \& of the International
Ruprecht, Göttingen.

Gibbons, R., 2006, House of God: House of the people of God, SPCK, London.

Gobel, D., 2011, 'Reforming church architecture', New Horizons, February, 6-7.

Gore, R.J., 2002, Covenantal worship: Reconsidering the Puritan regulative principle, $P \& R$, Phillipsburg, NJ.

Howkins, C., 1980, Discovering church furniture, Shire, Aylesbury, Buckinghamshire.

Kilde, J.H., 2008, Sacred power, sacred space: An introduction to Christian architecture and worship, Oxford University Press, Oxford.

Kirschner, J., 2009, 'Contemporary protestant liturgical space: Czech situation in the Wider context - An ecumenical point of view', Master's thesis, Charles University in Prague.

Lambert, A.T., 1998, 'Preaching, praying, and policing the reform in sixteenth-century Geneva', PhD thesis, University of Wisconsin-Madison.

Lamm, K., 2017, Nine reasons people aren't singing in worship, viewed 26 April 2017 from www.RenewingWorshipNC.org
Maag, K., 2016, Lifting hearts to the Lord: Worship with John Calvin in sixteenthcentury Geneva, Eerdmans, Grand Rapids, MI.

Macnutt, J., 2010, Building for democracy, Formac, Halifax.

Marvell, J., 1984, 'The English place of worship: A phenomenological study', PhD thesis, University of Leicester.

Old, H.O., 1984, Worship that is reformed according to scripture, John Knox, Atlanta, GA.

Saint Andrew's Chapel, Florida, 2017, Our Place of Worship: The Sanctuary, viewed 13 December 2017, from http://sachapel.com/about/who-we-are/our-placeworship.html

Seasoltz, K., 2005, A sense of the sacred: Theological foundations of Christian architecture and art, Continuum/Bloomsbury, New York.

Spicer, A., 2002, “'Qui est de Dieu, oit la parole de Dieu”: The Huguenots and their temples', in R.A. Mentzer \& A. Spicer (eds.), Society and culture in the Huguenot World 1559-1685, pp. 175-192, Cambridge University Press, Cambridge.

Spicer, A., 2003, "'Accommodating of Thame Selfis to Heir the Worde": Preaching, pews and reformed worship in Scotland, 1560-1638', History 88, 405-422. https://doi.org/10.1111/1468-229X.00270

Spicer, A., 2011, "'What kinde of house a Kirk is": Conventicles, consecrations and the concept of sacred space in post-Reformation Scotland', in W. Coster \& A. Spice (eds.), Sacred space in early modern Europe, pp. 81-103, Cambridge University Press, Cambridge.

Starke, J., 2011, Should churches spend money on nice buildings, viewed 08 May 2017 from https://www.thegospelcoalition.org/article/should-churches-spend-moneyon-nice-buildings

Stranmillis Evangelical Presbyterian Church, 2015, Stranmillis evangelical Presbyterian Church: Building project, Stranmillis Evangelical Presbyterian Church, Belfast.

Taylor, R., 2003, How to read a church: A guide to symbols and images in churches and Cathedrals, Hidden Spring, Mahwah, NJ.

White, J.F., 1990, Introduction to Christian worship revised edition, Abingdon, Nashville, TN.

Whittle, D., 1968, Christianity and the arts, Mowbray, London.

Whytock, J.C., 2014, 'Scottish liturgics and church architecture, a study of a transplanted kirk on Prince Edward Island', Journal of the Society for the Study of Architecture in Canada 39(2), 53-64.

Wilson, L., 2001, 'Suggestions toward reflecting and reinforcing principles of biblically reformed worship in our church buildings', Ordained Servants 10(4), 87-88.

Working, C.R., 2013, 'Re-presenting the tradition: Towards an architectural iconology of early modern French Protestantism, 1535-1623', PhD thesis, Fuller Theological Seminary.

Yates, N., 2008, Liturgical space: Christian worship and church buildings in Western Europe 1500-2000, Ashgate, Aldershot.

Yates, N., 2009, Preaching, word and sacrament: Scottish church interiors, 1560-1860, T \& T Clark, Edinburgh. 